\title{
Loss of alanine-glyoxylate
} and serine-pyruvate aminotransferase expression accelerated the progression of hepatocellular carcinoma and predicted poor prognosis

Yufeng Sun ${ }^{1,2+}$, Wenchao $\mathrm{Li}^{3,6+}$, Shiqi Shen ${ }^{1 \dagger}$, Xuejing Yang ${ }^{4}$, Bing Lu ${ }^{5}$, Xiaojing Zhang ${ }^{5}$, Peng Lu' ${ }^{1}$, Yi Shen ${ }^{3^{*}}$ and Juling $\mathrm{Ji}^{\mathrm{i}^{*}}$

\begin{abstract}
Background: Accumulated studies reported abnormal gene expression profiles of hepatocellular carcinoma (HCC) by cDNA microarray. We tried to merge cDNA microarray data from different studies to search for stably changed genes, and to find out better diagnostic and prognostic markers for HCC.

Methods: A systematic review was performed by searching publications indexed in Pubmed from March 1, 2001 to July 1,2016 . Studies that reporting CDNA microarray profiles in HCC, containing both tumor and nontumor data and published in English-language were retrieved. The differentially expressed genes from eligible studies were summarized and ranked according to the frequency. High frequency genes were subjected to survival analyses. The expression and prognostic value of alanine-glyoxylate and serine-pyruvate aminotransferase (AGXT) was further evaluated in HCC datasets in Oncomine and an independent HCC tissue array cohort. The role of AGXT in HCC progression was evaluated by proliferation and migration assays in a human HCC cell line.
\end{abstract}

Results: A total of 43 eligible studies that containing 1917 HCC patients were included, a list of 2022 non redundant abnormally expressed genes in HCC were extracted. The frequencies of reported genes were ranked. We finally obtained a list of only five genes (AGXT; ALDOB; CYP2E1; IGFBP3; TOP2A) that were differentially expressed in tumor and nontumor tissues across studies and were significantly correlated to HCC prognosis. Only AGXT had not been reported in HCC. Reduced expression of AGXT reflected poor differentiation of HCC and predicts poor survival. Knocking down of AGXT enhanced cell proliferation and migration of HCC cell line.

Conclusions: The present study supported the feasibility and necessity of systematic review on discovering new and reliable biomarkers for HCC. We also identified a list of high frequency prognostic genes and emphasized a critical role of AGXT deletion during HCC progression.

Keywords: Hepatocellular carcinoma, Systematic review, Alanine-glyoxylate and serine-pyruvate aminotransferase, Diagnostic marker, Prognostic marker

\footnotetext{
*Correspondence: sunny@ntu.edu.cn; jijuling@ntu.edu.cn

†Y Yfeng Sun, Wenchao Li and Shiqi Shen contributed equally to this work

${ }^{1}$ Department of Pathology, Medical School of Nantong University,

Nantong, China

${ }^{3}$ Department of Epidemiology and Medical Statistics, Public Health

School of Nantong University, Nantong, China

Full list of author information is available at the end of the article
}

(c) The Author(s) 2019. This article is distributed under the terms of the Creative Commons Attribution 4.0 International License (http://creativecommons.org/licenses/by/4.0/), which permits unrestricted use, distribution, and reproduction in any medium, provided you give appropriate credit to the original author(s) and the source, provide a link to the Creative Commons license, and indicate if changes were made. The Creative Commons Public Domain Dedication waiver (http://creativecommons.org/ publicdomain/zero/1.0/) applies to the data made available in this article, unless otherwise stated. 


\section{Background}

Liver cancer is the third leading cause of cancer death and the sixth most common cancer worldwide [1]. Hepatocellular carcinoma (HCC) accounts for $70-85 \%$ of the total liver cancer burden. The accurate diagnosis and proper treatment of $\mathrm{HCC}$ is particularly challenging. Options for $\mathrm{HCC}$ treatment remain limited, surgical resection is considered the only "curative treatment". But HCC patients do not have overt symptoms in the early stages, $80 \%$ of patients have widespread HCC at the time of diagnosis and are not candidates for surgical treatment. Even with surgical resection, the 5-year survival rate is poor (about 38\%) [2].

Accumulated data from high-throughput analyses by cDNA microarray provide an accurate landscape of gene expression in $\mathrm{HCC}$, and revealed a lot of pathogenic and prognostic genes for HCCs, thus enabled us to delineate some of the key events that might dominate tumor development and progression. Hopefully, translation of this knowledge into new targets and biomarkers might impact HCC decision making, and ultimately improve patient's outcomes [3]. However, these studies were performed with different platforms and in different populations, the suggested diagnostic markers and potential therapeutic targets for HCC varied across studies, hence prevented the application of these findings. It's the high time to merge these cDNA microarray data from different studies using different platforms, to search those widely and stably changed genes, and to find out better diagnostic markers and potential therapeutic targets for HCC.

In the present study, we performed a systematic review of studies that reported cDNA microarray data for both tumor and nontumor liver tissues of HCC patients and came up with a list of five genes that were differentially expressed in tumor and nontumor tissues across different studies and were significantly correlated to HCC prognosis. Among the five genes, except for alanine-glyoxylate and serine-pyruvate aminotransferase (AGXT) which is an essential gene involved in glyoxylate detoxification, the other four genes were well documented in HCC. Here, we reported that AGXT was involved in the progression of HCC and loss of AGXT expression predicted poor prognosis of HCC. AGXT might be a novel diagnostic and prognostic marker and a potential therapeutic target for $\mathrm{HCC}$.

\section{Methods}

\section{Data sources and search strategy}

Literature retrieval was originally performed with PubMed, a free search engine accessing primarily the MEDLINE database of references and abstracts on life sciences and biomedical topics. The relevant Mesh
Terms were chose as the key words, including hepatocellular carcinoma, liver neoplasms, gene expression profiling, human, gene expression regulation, oligonucleotide array sequence analysis. Date of publications was restricted to July 2016. Besides, the literature must be published in English language. In addition to use ((()((carcinoma, hepatocellular[MeSH Terms]) AND liver neoplasms[MeSH Terms]) AND gene expression profiling[MeSH Terms]) AND human[MeSH Terms]) AND gene expression regulation[MeSH Terms]) AND oligonucleotide array sequence analysis[MeSH Terms])) AND (“1781/01/01”[Date-MeSH]: “2016/06/30”[Date$\mathrm{MeSH}]$ ) as the search strategy to obtain literatures, we also reviewed the bibliographies of eligible studies as well as those of relevant review articles to identify additional studies not captured by our database searches. To identify all potentially eligible studies, two investigators independently conducted structured searches in selected databases.

\section{Study inclusion criteria}

Eligible studies were included in the systematic review if they met the following criteria: (1) they were gene expression studies in hepatocellular carcinoma; (2) they used tissue samples obtained from surgically resected tumor and corresponding non-tumor or normal tissues in human for comparison; (3) validation of method and sample set were reported; (4) clinical and experimental study. Articles were excluded based on the following criteria: (1) review articles or letters; (2) non-liver cancer; (3) non-gene expression profile; (4) non-human tissue samples.

\section{Data extraction}

From the full text and corresponding additional information, the following items were eligible to collect and record for each study: authors, year of publication, region, selection number and characteristics of recruited liver cancer patients, the members of abnormally expressed genes in liver cancer. Two investigators (K. D. and YL. J.) independently evaluated and extracted the data with the inclusion criteria. Conflicts in study selection at this stage were resolved by consensus, referring back to the original article in consultation with the principal.

\section{Gene statistics and screening}

For genes that have multiple names/synonyms, we standardized the gene name for later work by using widely accepted and used HGNC database (https:// www.genenames.org/). Frequency and composition analysis of the abnormally expressed genes in hepatocellular carcinomas were conducted by IBM SPSS Statistics 20.0 software (Endicott, New York, NY). 
The genes presented in more than four studies were regarded as high frequent genes. The expression of the high frequent genes in other malignant tumors were obtained from Oncomine (https://www.oncom ine.org/). To identify a prognostic gene list across different studies, the prognostic value of these high frequent genes were evaluated by survival risk prediction in a previously described cohort of 247 Chinese HCC patients with publicly available Affymetrix U133A array data (National Center for Biotechnology Information [NCBI] Gene Expression Omnibus [GEO] Accession number GSE14520) [4]. BRB-Array Tools (version 4.3.1) was used for survival risk prediction. By reviewing related publications, the prognostic genes that have been intensively investigated were excluded, and the only one gene AGXT (alanine-glyoxylate and serinepyruvate aminotransferase) that had not been reported in $\mathrm{HCC}$ were chosen for further validation.

\section{Tissue microarray and immunohistochemistry staining}

Tissue microarrays of 192 HCC patients were used for validation. All of the patients underwent curative hepatectomy for primary HCC at the Affiliated Hospital of Nantong University between March 2004 and August 2009. No patients received either radiotherapy or chemotherapy before the surgery. The study was performed on the basis of the protocol approved by the Declaration of Helsinki, and written informed consent was obtained from all patients. The histological Grading of HCC was defined according to the Edmondson-Steiner grading system. In the present study, grade I and II were termed as well differentiated, grade III was termed as moderate differentiated, and grade IV was termed as poor differentiated. Tumor stage was assigned according to the American Joint Committee on Cancer TNM staging. Patients were followed up every 2-3 months during the 1st year after surgery and every 3-6 months thereafter until September 2016. Totally 101 out of the 192 HCC patients had integrated clinical and follow up data (Additional file 1: Table S1).

Immunohistochemistry was performed with Envision + kits (DAKO, Carpinteria, CA) according to the manufacturer's instructions [4], of which positive staining appeared in brown. The primary antibodies used were rabbit anti-AGXT monoclonal antibody (1:100, Abcam). Immunostained slides were analyzed with a semi quantitative scoring approach which combined staining intensity and percentage of positive cells: grade 0 for no reaction or focal weak reaction; grade 1 for intense focal or diffuse weak reaction; grade 2 for moderate diffuse reaction; and grade 3 for intense diffuse reaction, and the corresponding slides were scored from 0 to 3 respectively. The staining scores were evaluated independently by two pathologists who were blinded to the clinical outcomes.

\section{Cell culture}

Human HCC cell lines were cultured in Dulbecco's Modified Eagle's Medium (DMEM) (Gibco, CA, USA) supplemented with $10 \%$ fetal bovine serum (FBS, Gibco, Carlsbad, USA) in a $5 \% \mathrm{CO}_{2}$ atmosphere at $37^{\circ} \mathrm{C}$.

\section{siRNA transfection}

Huh-7 cells were seeded into 6-well culture plates and transfected with small interfering RNAs (siRNAs) against human AGXT (siAGXT) (SASI_Hs01_00153951, SASI Hs01_00153952 and SASI_Hs01_00153953, Sigma) using Lipofectamine ${ }^{\mathrm{TM}} 2000$ (Invitrogen, Carlsbad, CA), at a final concentration of $75 \mathrm{~nm}$. Non-targeting control siRNA (siNC, Sigma) was used as negative control. Cy3 labeled siRNA transfection control (Cy3-siTC, RiboBio, Guangzhou, China) was used to optimize siRNA concentration for transfection. Knockdown efficiency was determined by real-time quantitative reverse transcription-PCR (RT-PCR) $48 \mathrm{~h}$ after the transfection.

\section{Real-time quantitative RT-PCR}

The RNAs from Huh-7 or HepG2 cells were reverse-transcribed with Thermoscript RT-PCR system (Invitrogen). Real-time quantitative PCR was performed on RotorGene 3000 instrument (Corbett Research, New South Wales, Australia) with SYBR qPCR master lit (TaKaRa, Dalian, China). Gene specific primers were: AGXT forward primer 5'-CTGGGGACTCCTTCCTGGTT-3', AGXT reverses primer $5^{\prime}$-CACCTCCTGCAGTGTGTA GT-3'; $\beta$-actin forward primer $5^{\prime}$-TTGTTACAGGAA GTCCCTTGCC- $3^{\prime}, \beta$-actin reverses primer $5^{\prime}$-ATGCTA TCACCTCCCCTGTGTG- $3^{\prime}$. Relative gene expression was normalized to housekeeping gene $\beta$-actin and calculated as $2-\Delta \mathrm{C}$.

\section{Western blot}

For western blot analysis, whole cell protein was extracted by RIPA lysis buffer (Beyotime, Shanghai) according to the manufacturer's instructions. Equal amounts of protein $(20 \mu \mathrm{g})$ were separated on 10\% SDS PAGE gel and transferred onto polyvinyldifluoride (PVDF) membranes (Millipore). PVDF membranes were blocked with 5\% non-fat milk for $1 \mathrm{~h}$, then incubated with specific primary antibodies for anti-AGXT antibody (Abcam, Cambridge, UK), and $\beta$-actin (CST, Boston, America) at $4{ }^{\circ} \mathrm{C}$ overnight, then incubated with horseradish peroxidase-conjugated secondary antibody for an additional $1 \mathrm{~h}$ at room temperature. The protein expression was visualized with the ECL chemiluminescence detection system (Biorad). 


\section{Proliferation and migration assays}

Proliferation ability of HCC cells was measured by cell counting using a Counting Chamber or Cell Counting Kit-8 reagent (CCK8, Dojindo Laboratories, Kumamoto, Japan) according to the manufacturer's recommendation. Cells were seeded at $1 \times 10^{5}$ cells per $25 \mathrm{~cm}^{2}$ Corning cell culture flask or $2 \times 10^{3}$ cells per well in 96-well plates and cultured for $0 \mathrm{~h}, 24 \mathrm{~h}, 48 \mathrm{~h}, 72 \mathrm{~h}, 96 \mathrm{~h}, 120 \mathrm{~h}$ and $144 \mathrm{~h}$. For cells cultured in 96-well plates, CCK8 solution was added $\left(10 \mu \mathrm{l}\right.$ each well) and incubated at $37{ }^{\circ} \mathrm{C}$ for $2 \mathrm{~h}$. The optical density readings at $450 \mathrm{~nm}$ were determined by a micro plate reader (Bio-Rad, Tokyo, Japan).

For transwell migration assays, a single cell suspension of 50,000 Huh-7 and HepG2 cells, or siAGXT/siNC treated Huh-7 cells resuspended in $200 \mu \mathrm{l}$ serum-free DMEM were plated in the upper chambers (Millicell, $8.0 \mu \mathrm{m}$; Corning, USA), $750 \mu \mathrm{l}$ DMEM medium with $10 \%$ FBS was used as a chemoattractant in the lower chambers. After $24 \mathrm{~h}$, nonmigrating cells were removed from the upper surface softly by a cotton swab. The cells that migrated through the membrane to the lower surface were fixed with $4 \%$ paraformaldehyde and stained with $0.5 \%$ crystal violet, then counted under a microscope (Olympus) at 200-fold magnification, five fields were counted for each well.

\section{Cell cycle assay and apoptosis assay}

HCC cells were seeded at $2 \times 10^{5}$ per well in 6 well plates. After overnight incubation, cells were treated with siAGXT or siNC for $72 \mathrm{~h}$. After treatment, HCC cells were digested using $0.25 \%$ pancreatic enzyme, washed twice with PBS, fixed in precooled $70 \%$ cold ethanol at $4{ }^{\circ} \mathrm{C}$ for $24 \mathrm{~h}$. Cells were centrifuged again, washed with cold PBS twice, and stained with Propidium iodide $(0.1 \mathrm{mg} / \mathrm{ml})$ (Propidium iodide, PI; Beyotime) at $37{ }^{\circ} \mathrm{C}$ in the dark for $30 \mathrm{~min}$. DNA contents were measured with a BD FACS Calibur system (BD Biosciences, Franklin Lake, NJ). Data were analyzed using ModFit LTTM software (Verity Software House, Topsham, ME). For apoptosis assay, cells were harvested, washed, and resuspended with PBS and stained with BD Annexin V-FITC Apoptosis Detection Kit. Data was acquired using a BD FACS Calibur system and BD FACSuite software (BD Biosciences).

\section{Statistical analysis}

Statistical analyses were performed with Graphpad Prism 6.0 (Graphpad Software, Inc., La Jolla, CA) or IBM SPSS Statistics 20.0 software (Endicott, New York, $\mathrm{NY}$ ). Quantitative data were expressed as mean \pm SD. Comparisons between groups were made by Student's t-test or two-way ANOVA. Categorical data were evaluated by the $\chi^{2}$ test. All P-values were two-sided and the statistical significance was defined as $\mathrm{P}<0.05$. All experiments were performed in triplicates.

\section{Results \\ Study selection and characteristics of included studies}

According to the literature retrieval strategy, 392 studies were identified in the initial search (Fig. 1). Based on the independent screening of titles and abstracts by two investigators (K. D. and YL. J.), 293 studies were excluded, of which 47 were animal studies, 34 were not performed with liver cancer tissues, 105 were not gene expression profiling studies, 107 articles were not correlated with the present study, and 99 papers remained. The full text of these remaining 99 studies was retrieved and further assessed for eligibility. Of these 99 publications, 56 were excluded (one was animal study, 3 were small RNA studies, 2 were review articles, 4 were nonHCC, 15 were excluded because they did not have gene expression profiling data, 4 studies had difficult in data extraction, 27 were excluded because they were irrelevant to our study). In total, 43 articles were included. All of these 43 articles were based on HCC cohort study containing a total of 1917 HCC patients. After a preliminary check of these 43 articles, we included "Author", "Year of publication", "Country", "Number of patients" (NP), "Number of significant genes" (NG),"Clinical tissue" (Tissue), "Contain adjacent tissue" (C\&A), "Hepatitis B surface antigen" (HBs-Ag), "Hepatitis $\mathrm{C}$ antibody" (HCV-Ab), "Alcoholism ", "Tumor size" (TS),"Tumor differentiations" (TD), and "AFP" as the baseline variables to characterize the enrolled studies. Thirteen studies contained the information of both hepatitis B surface antigen ( $\mathrm{HBs}-\mathrm{Ag}$ ) and hepatitis $\mathrm{C}$ antibody ( $\mathrm{HCV}-\mathrm{Ab})$, seven studies only enrolled person carrying $\mathrm{HCV}-\mathrm{Ab}$, four studies only included patients carrying HBs-Ag, and two studies had the information of alcoholism. So we combined these three variables into the variable "Etiology". Only six articles provided the record of tumor size, of which four articles [5-8] used $5 \mathrm{~cm}$ and two articles $[9,10]$ used $3 \mathrm{~cm}$ to distinguish large or small tumor. The differentiation of tumors was described as highly, moderately and poorly differentiated in four articles [5, 11-13]. Few literatures discussed AFP. Due to the excessive missing information for tumor size, tumor differentiation and AFP, only "Author", "Year of publication", "Country", "Number of patients" (NP), "Number of significant genes" (NG),"Clinical tissue" (Tissue), "Contain adjacent tissue" (C\&A) and "Etiology" were included. These main characteristics of the 43 studies were summarized in Table 1. 


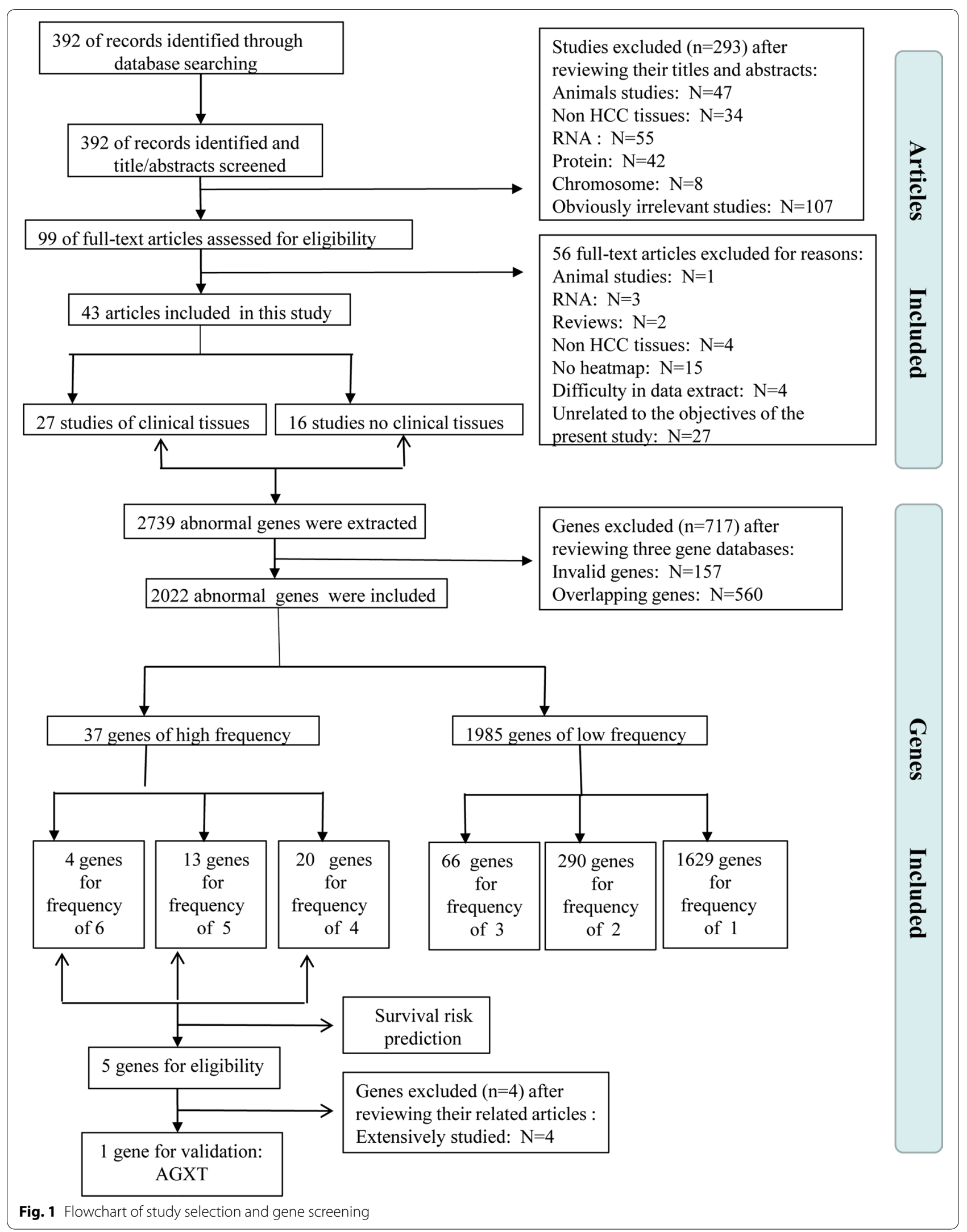


Table 1 Characteristics of the 43 included studies

\begin{tabular}{|c|c|c|c|c|c|c|c|}
\hline Article & Year of publication & Country & NP & NG & Tissue & $C \& A$ & Etiology \\
\hline Engelmann [14] & 2015 & Germany & 15 & 30 & $\mathrm{~F}$ & T & \\
\hline Itzel [15] & 2015 & USA & 163 & 61 & $\mathrm{~F}$ & $\mathrm{~F}$ & \\
\hline Yu [16] & 2015 & China & 154 & 67 & T & $\mathrm{F}$ & HBV \\
\hline Shi [17] & 2014 & China and Singapore & 26 & 6 & T & $\mathrm{F}$ & \\
\hline Mayinuer [18] & 2013 & Japan & 152 & 154 & T & $\mathrm{F}$ & \\
\hline Gehrau [19] & 2012 & USA & 107 & 17 & $\mathrm{~F}$ & $\mathrm{~F}$ & $\mathrm{HCV}$ \\
\hline Nagai [11] & 2012 & Japan & 21 & 25 & T & $\mathrm{F}$ & $\mathrm{HCV}$ \\
\hline Roessler [20] & 2012 & China & 76 & 6 & $\mathrm{~F}$ & $\mathrm{~F}$ & HBV \\
\hline Sato [21] & 2012 & Japan & 48 & 20 & T & $\mathrm{F}$ & $\mathrm{HCV}$ \\
\hline Yu [22] & 2012 & China & 100 & 59 & T & $\mathrm{F}$ & HBV \\
\hline Zekri [23] & 2012 & Egypt & 31 & 25 & T & T & $\mathrm{HCV}$ \\
\hline Satow [24] & 2010 & Japan & 84 & 124 & T & T & \\
\hline De Giorgi [25] & 2009 & Italy & 21 & 39 & $\mathrm{~F}$ & $\mathrm{~F}$ & $\mathrm{HCV}$ \\
\hline Sugawara [26] & 2010 & Japan & $1 \mathrm{CL}$ & 36 & $\mathrm{~F}$ & $\mathrm{~F}$ & \\
\hline Derambure [12] & 2008 & France & 40 & 63 & T & $\mathrm{F}$ & HBV, HCV, alcoholism \\
\hline Gao [9] & 2008 & Japan & 38 & 24 & $\mathrm{~T}$ & T & $\mathrm{HCV}, \mathrm{HBV}$ \\
\hline Guo [27] & 2008 & China & $3 \mathrm{CL}$ & 17 & $\mathrm{~F}$ & $\mathrm{~F}$ & \\
\hline Hamaguchi [10] & 2008 & Japan & 60 & 22 & $\mathrm{~T}$ & $\mathrm{~F}$ & \\
\hline Kittaka [5] & 2008 & Japan & 100 & 25 & T & $\mathrm{F}$ & $\mathrm{HCV}, \mathrm{HBV}$ \\
\hline Sakai [13] & 2008 & Japan & 12 & 93 & $\mathrm{~F}$ & $\mathrm{~T}$ & $\mathrm{HCV}$ \\
\hline Skawran [28] & 2008 & Germany & 32 & 185 & $\mathrm{~F}$ & $\mathrm{~F}$ & $\mathrm{HBV}, \mathrm{HCV}$ \\
\hline Yamashita [29] & 2008 & China & 40 & 71 & T & $\mathrm{F}$ & HBV \\
\hline Lin [30] & 2007 & Taiwan & - & 19 & $\mathrm{~F}$ & $\mathrm{~F}$ & \\
\hline Liu [31] & 2007 & China & 1 & 45 & $\mathrm{~T}$ & $\mathrm{~F}$ & \\
\hline Wang [32] & 2007 & Singapore & 80 & 57 & $\mathrm{~T}$ & $\mathrm{~F}$ & $\mathrm{HCV}, \mathrm{HBV}$ \\
\hline Wang [33] & 2007 & USA & 14 & 134 & $\mathrm{~F}$ & $\mathrm{~F}$ & \\
\hline Danenberg [34] & 2006 & USA & $1 \mathrm{CL}$ & 50 & $\mathrm{~F}$ & $\mathrm{~F}$ & \\
\hline Chen [35] & 2005 & USA & 63 & 54 & $\mathrm{~F}$ & $\mathrm{~F}$ & \\
\hline Ge [36] & 2005 & Japan & 36 & 58 & $\mathrm{~F}$ & $\mathrm{~F}$ & \\
\hline lizuka [37] & 2005 & Japan & 76 & 110 & $\mathrm{~T}$ & $\mathrm{~F}$ & $\mathrm{HCV}, \mathrm{HBV}$ \\
\hline Matoba [38] & 2005 & Japan & 33 & 46 & $\mathrm{~T}$ & $\mathrm{~F}$ & $\mathrm{HCV}, \mathrm{HBV}$ \\
\hline Nam [6] & 2005 & Korea & 42 & 92 & $\mathrm{~T}$ & $\mathrm{~F}$ & \\
\hline Wong [39] & 2005 & China & 10 & 55 & $\mathrm{~F}$ & $\mathrm{~F}$ & $\mathrm{HBV}, \mathrm{HCV}$ \\
\hline Breuhahn [40] & 2004 & Germany & 39 & 118 & $\mathrm{~T}$ & $\mathrm{~T}$ & HBV, HCV, alcoholism \\
\hline Chen [41] & 2004 & USA & - & 29 & $\mathrm{~T}$ & $\mathrm{~F}$ & \\
\hline Lee [7] & 2004 & Korea & 10 & 20 & $\mathrm{~T}$ & $\mathrm{~F}$ & $\mathrm{HCV}, \mathrm{HBV}$ \\
\hline Kurokawa [42] & 2004 & Japan & 20 & 63 & $\mathrm{~T}$ & $\mathrm{~F}$ & $\mathrm{HBV}, \mathrm{HCV}$ \\
\hline Smith [8] & 2003 & USA & 20 & 50 & $\mathrm{~T}$ & $\mathrm{~F}$ & $\mathrm{HCV}$ \\
\hline Kim [43] & 2003 & USA & 74 & 30 & $\mathrm{~T}$ & $\mathrm{~F}$ & \\
\hline Chung [44] & 2002 & Korea & 8 & 62 & $\mathrm{~T}$ & T & \\
\hline lizuka [45] & 2002 & Japan & 51 & 83 & T & F & $\mathrm{HBV}, \mathrm{HCV}$ \\
\hline Lee [46] & 2002 & USA & $19 \mathrm{CL}$ & 119 & $\mathrm{~F}$ & $\mathrm{~F}$ & \\
\hline Okabe [47] & 2001 & Japan & 20 & - & T & T & $\mathrm{HBV}, \mathrm{HCV}$ \\
\hline
\end{tabular}

$N P$ number of patients, NG number of significant genes, Tissue clinical tissue, C\&A contain adjacent tissue, $C L$ cell line, $T$ true, $F$ false

\section{Abnormally expressed genes in HCC across different} studies

Totally 2739 abnormally expressed genes in HCC were extracted from the 43 studies. After standardization of gene names according to HGNC database (https://www. genenames.org/), 2576 genes remained (including repetitive). When repetitive genes were excluded by SPSS 20.0, 2022 non-redundant genes remained (Fig. 1). The 
frequency of each gene that appeared in the 43 studies included was counted. The frequency ranged from 1 to 6 , with 6 the highest frequency, while 1 the lowest frequency (Fig. 2, Additional file 2: Table S2). Proportion of frequency 6 was the minimum, the frequency 1 constituted the largest proportion of all. Genes that appeared $\geq 4$ times were regarded as genes of high frequency genes (37 genes), and genes that appeared $\leq 3$ times were regarded as genes of low frequency (1985 genes). There are four genes that appeared in six studies $(0.2 \%)$, including C8A, MT1E, MT1H and NNMT; 13 genes appeared in five studies (0.6\%), including: AFP, ALDOB, C9, CXCL12, CYP2E1, HPX, IGF2, IGFBP3, MT1F, MT2A, RAF1, SULT1E1 and TOP2A; 20 genes appeared in four studies (1.0\%), including: AGXT, AKR1B10, BCL2, C4A, C6, CES1, CLU, CYP2E1, EPCAM, FCN3, FDPS, FOS, GPC3, MFSD2A, PDCD4, PPIB, RGS5, SAA1, SAA4 and TAT; 66 genes appeared in three studies (3.3\%); 290 genes appeared in two studies (14.3\%); 1629 genes only appeared once (80.6\%).

The publication history of these 37 high frequent genes in HCC was searched in Pubmed (Additional file 3: Table S3). About half of these genes have been extensively studied in HCC and appeared in more than 5 directly related studies, including: AFP on the top with 824 publications, followed by EPCAM, GPC3, CYP2E1, FOS, BCL2, IGF2, CXCL12, AKR1B10, PDCD4, TAT,

\section{Frequency of the abnormally expressed genes in HCC}

\begin{tabular}{cccc}
\hline Group & Frequency & $\begin{array}{c}\text { Relative } \\
\text { Percent }\end{array}$ & $\begin{array}{c}\text { Cumulative } \\
\text { Percent }\end{array}$ \\
\hline 1 & 1629 & 80.6 & 80.6 \\
2 & 290 & 14.3 & 94.9 \\
3 & 66 & 3.3 & 98.2 \\
4 & 20 & 1.0 & 99.2 \\
5 & 13 & 0.6 & 99.8 \\
6 & 4 & 0.2 & 100 \\
\hline
\end{tabular}

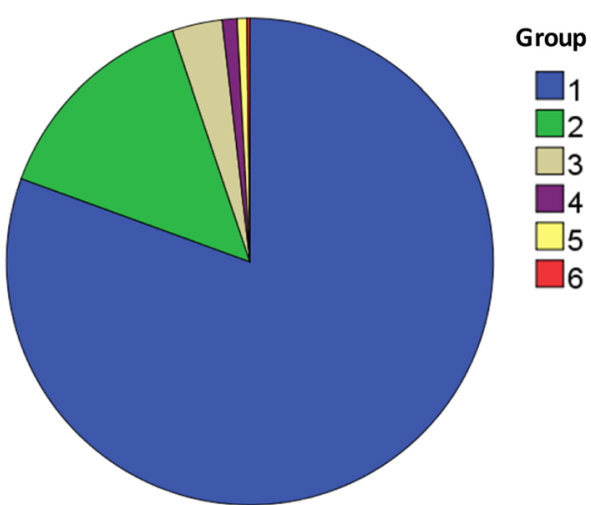

Fig. 2 Frequency analysis of the abnormally expressed genes in hepatocellular carcinoma. Data presented in the frequency table and pie chart were from the 43 studies included
RAF1, IGFBP3 and TOP2A, while seven genes has not been reported in $\mathrm{HCC}$ by the time of literature searching, including: AGXT, FCN3, FDPS, MFSD2A, RGS5, SAA1 and SAA4. The relative expression of these 37 high frequent genes in liver cancer and other malignant tumors were obtained from Oncomine (https://www.oncomine. org/) and provided in Additional file 3: Table S3.

\section{Genes significantly associated with the survival of HCC patients}

The prognostic value of the 37 high frequent genes were evaluated by survival risk prediction in a previously described cohort of 247 Chinese HCC patients with publicly available Affymetrix U133A array data (Gene Expression Omnibus accession number GSE14520) [4]. BRB-Array Tools (version 4.3.1) was used for survival risk prediction. Among the 37 genes, under-expression of three genes (alanine-glyoxylate and serine-pyruvate aminotransferase, AGXT; aldolase B, ALDOB; cytochrome P450 family 2 subfamily E member 1, CYP2E1) and overexpression of two genes (insulin-like growth factor binding protein-3, IGFBP3; topoisomerase $2 \alpha$, TOP2A) were significantly correlated to poor prognosis (Fig. 3). By literature reviewing, among the five genes, four have been well documented in HCC, including: ALDOB [48-50], IGFBP3 [51-53], CYP2E1 [54-56] and TOP2A [57, 58], while AGXT was mostly studies in primary hyperoxaluria type $1[59,60]$, there are little reports of AGXT in HCC. Thus, AGXT was chosen for further validation.

\section{AGXT was highly expressed in liver but lost in HCC}

According to the mRNA expression in normal human tissues from GTEx, Illumina, BioGPS, and CGAP SAGE for AGXT gene; as well as protein expression in normal tissues and cell lines from ProteomicsDB, MaxQB, and MOPED for AGXT gene, we found that AGXT was highly expressed in liver, fetal liver and liver secretome (Additional file 4: Figure S1, https://www.genecards. org/). AGXT protein is mostly localized in the peroxisomes where it is involved in glyoxylate detoxification. The expression of AGXT in HCC vs. normal liver were searched and analyzed by Oncomine (https://www. oncomine.org/). The differential AGXT mRNA expression analyses between HCC vs. normal were feasible in four datasets, including: Roessler Liver 2 [61], Chen Liver [62], Wurmbach Liver [63] and Roessler Liver [61], totally containing data from 327 livers and 385 HCC tissues. Compared to normal liver, the expression of AGXT mRNA significantly decreased in HCC in all of the four datasets with the fold-changes ranged from -3.694 to -6.176 , P-values ranged from $1.92 \mathrm{E}-35$ to $4.20 \mathrm{E}-5$ (Fig. 4). The cohort used for survival risk prediction of 

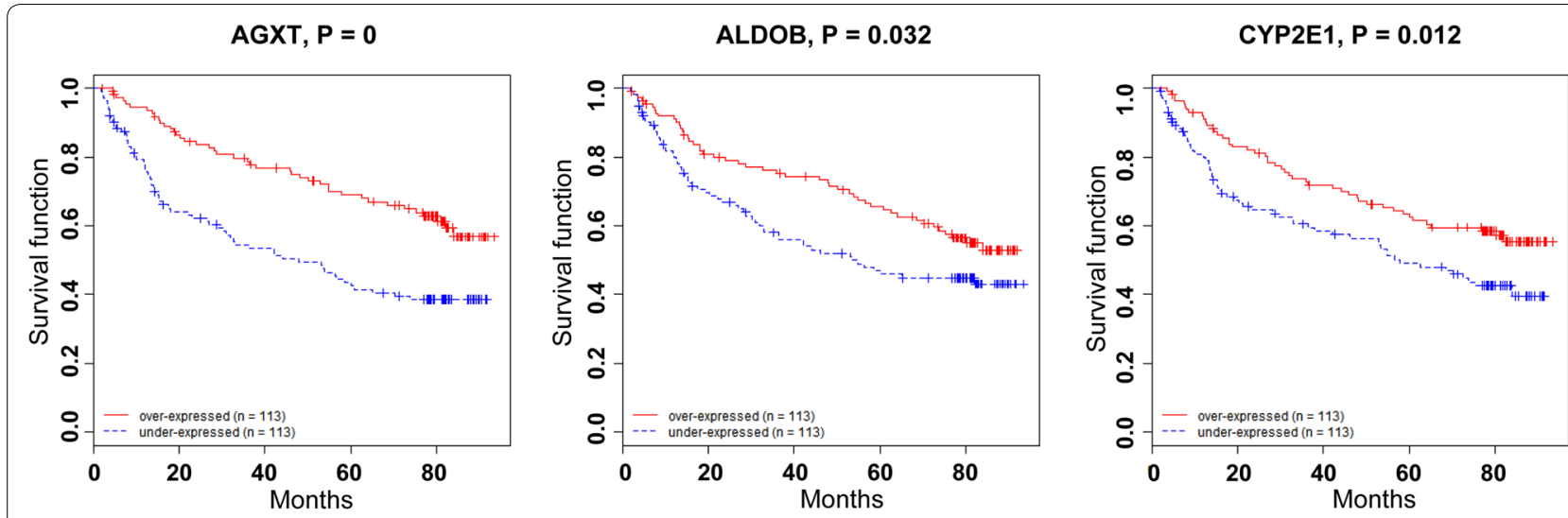

IGFBP3, P = 0.028
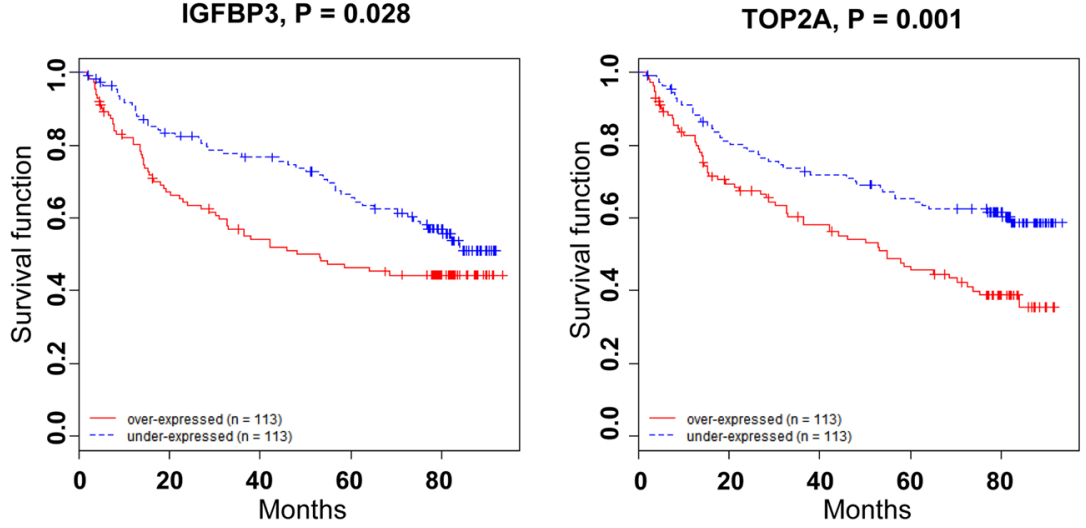

Fig. 3 The expression of AGXT, ALDOB, CYP2E1, IGFBP3 and TOP2A predicted clinical outcome in HCC. The prognostic value of the 37 high frequent genes was evaluated by survival risk prediction in a cohort of 247 Chinese HCC patients (Gene Expression Omnibus Accession number GSE14520). BRB-Array Tools (version 4.3.1) was used for survival risk prediction. Among the 37 genes, under-expression of three genes (alanine-glyoxylate and serine-pyruvate aminotransferase, AGXT; aldolase B, ALDOB; cytochrome P450 family 2 subfamily E member 1, CYP2E1) and over-expression of two genes (insulin-like growth factor binding protein-3, IGFBP3; topoisomerase 2a, TOP2A) were significantly correlated to poor prognosis. Red line represented samples with over-expressed gene, and blue line represented samples with under-expressed gene

the 37 high frequent genes was partially overlapped with Roessler Liver 2 [20, 61].

The differential expression of AGXT in liver and HCC was validated by immunohistochemistry (IHC) study with tissue microarray from an independent cohort of 192 HCC patients. Comparison of AGXT by IHC between exactly paired HCC tumor and nontumor tissues was applicable in 87 cases. The IHC staining of AGXT in nontumor liver tissues was strongly positive and was characterized by a granular, diffuse, cytoplasmic staining pattern; while in tumor tissues, the staining of AGXT on malignant hepatocytes were focal and/or pale in a majority of cases (Fig. 5a). Immunostained slides were analyzed with a semi quantitative scoring approach as described in "Methods", and were scored from 0 to 3 according to the staining intensity (Fig. 5b). The IHC observation reaffirmed that AGXT was highly expressed in nontumor liver tissues and was down-regulated in HCC tumor tissues $(\mathrm{P}<0.0001)$ (Fig. 5c).

\section{Loss of AGXT expression was correlated with a poor prognosis and differentiation of HCC}

As described earlier, under-expression of AGXT correlated to poor prognosis in HCC cohort GSE14520 (Fig. 3), we tried to verify the prognostic value of AGXT in this tissue array HCC cohort. Totally 101 out of the 192 HCC patients that had integrated clinical and follow up data were included, and were divided into two groups based on IHC scores: AGXT high (IHC score 2 and $3, \mathrm{n}=60$ ) and AGXT low (IHC score 0 and $1, \mathrm{n}=41$ ) (Fig. 5b). Overall survival was compared between AGXT high and low cases. It confirmed that low expression of AGXT was associated with poor prognosis $(\mathrm{P}=0.0348)$ (Fig. $5 \mathrm{~d})$.

When examining the immunostained HCC slides, we noticed that the staining of AGXT tended to be stronger in well differentiated $\mathrm{HCC}$, but weaker or totally lost in poorly differentiated HCC. Combined with the above finding that AGXT was highly expressed in nontumor liver but down-regulated in $\mathrm{HCC}$, we wondered that if AGXT 


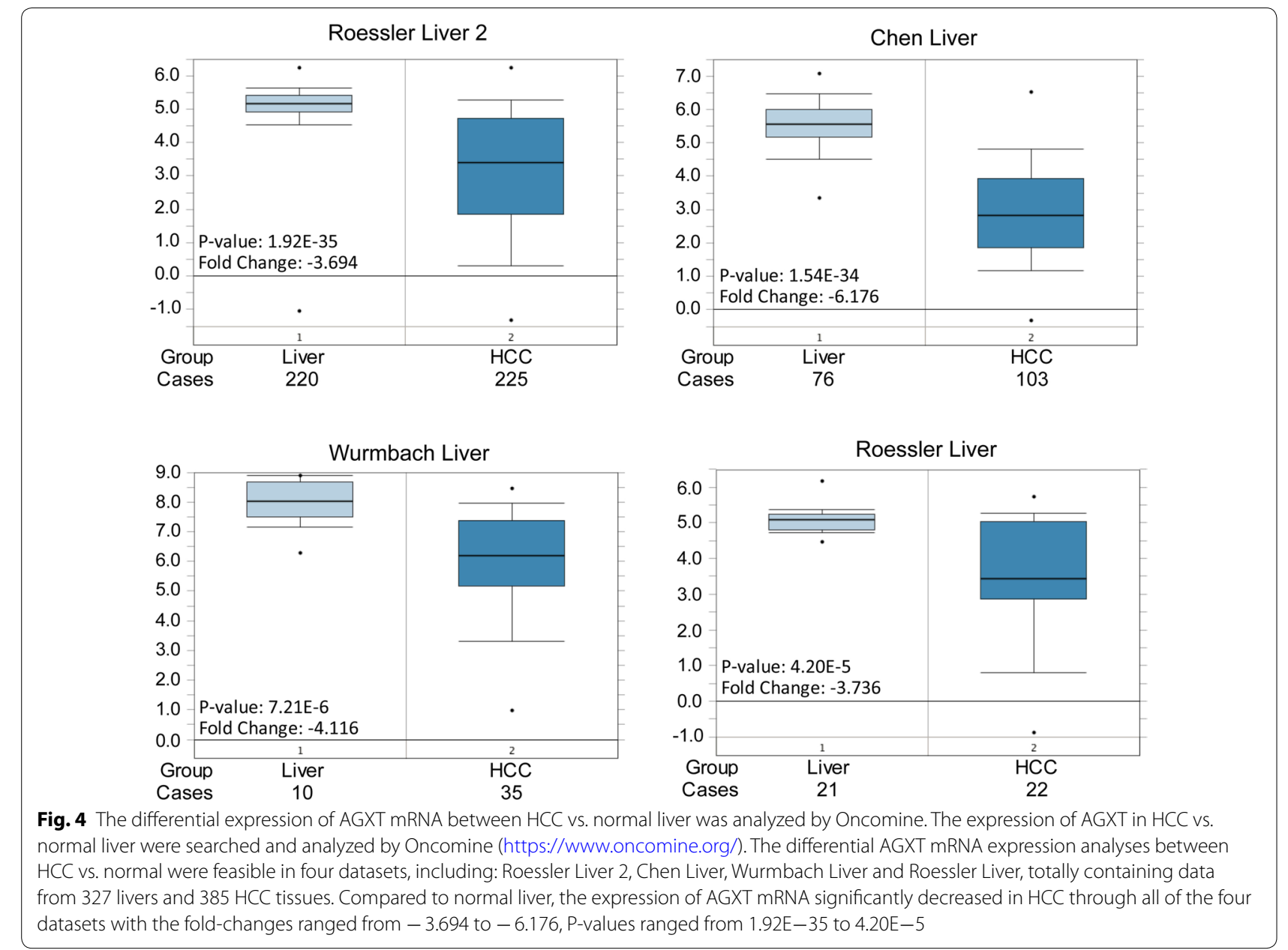

expression represented the degree of hepatocyte differentiation and maturation. We then compared the IHC score of AGXT among well, moderate and poorly differentiated HCCs. All of the $192 \mathrm{HCC}$ patients were involved. The well differentiated HCCs showed the highest score of AGXT, while the poorly differentiated HCCs scored the lowest. The expression of AGXT in HCC was significantly associated to tumor differentiation $(\mathrm{P}<0.0001)$ (Fig. 5e).

To further explore the clinical parameters associated with AGXT in HCC, we investigated the correlation between AGXT expression and clinicopathological characteristics by performing univariate Cox proportional hazards regression analyses. The $101 \mathrm{HCC}$ patients that had integrated clinical data were included. We found that AGXT expression levels only related to tumor differentiation $(\mathrm{P}<0.0001)$, and there was no significant correlation with patient's age, gender, serum AFP, tumor size, TNM stage, tumor number, vascular invasion, portal vein tumor thrombus and liver cirrhosis (Table 2). The above observations suggested that reduced expression of AGXT related to tumor differentiation and predicted poor prognosis in HCC.

(See figure on next page.)

Fig. 5 Protein expression of AGXT in HCC and the correlation to prognosis and tumor differentiation. a The protein expression of AGXT in paired nontumor $(\mathrm{N})$ and tumor $(\mathrm{T})$ tissues from HCC patients was detected by immunohistochemistry (IHC). $\mathbf{b}$ Immunostained slides were scored from 0 to 3 according to staining intensity and percentage of positive cells. c AGXT IHC scoring of 87 paired HCC samples which contained both nontumor $(\mathrm{N})$ and matched tumor ( $\mathrm{T}$ ) tissues. d Kaplan-Meier survival analysis for $101 \mathrm{HCC}$ patients based on AGXT expression, $\mathrm{P}=0.0227$. e The AGXT expression in well, moderate and poor differentiated HCC, ${ }^{* * *} \mathrm{P}<0.0001$ 


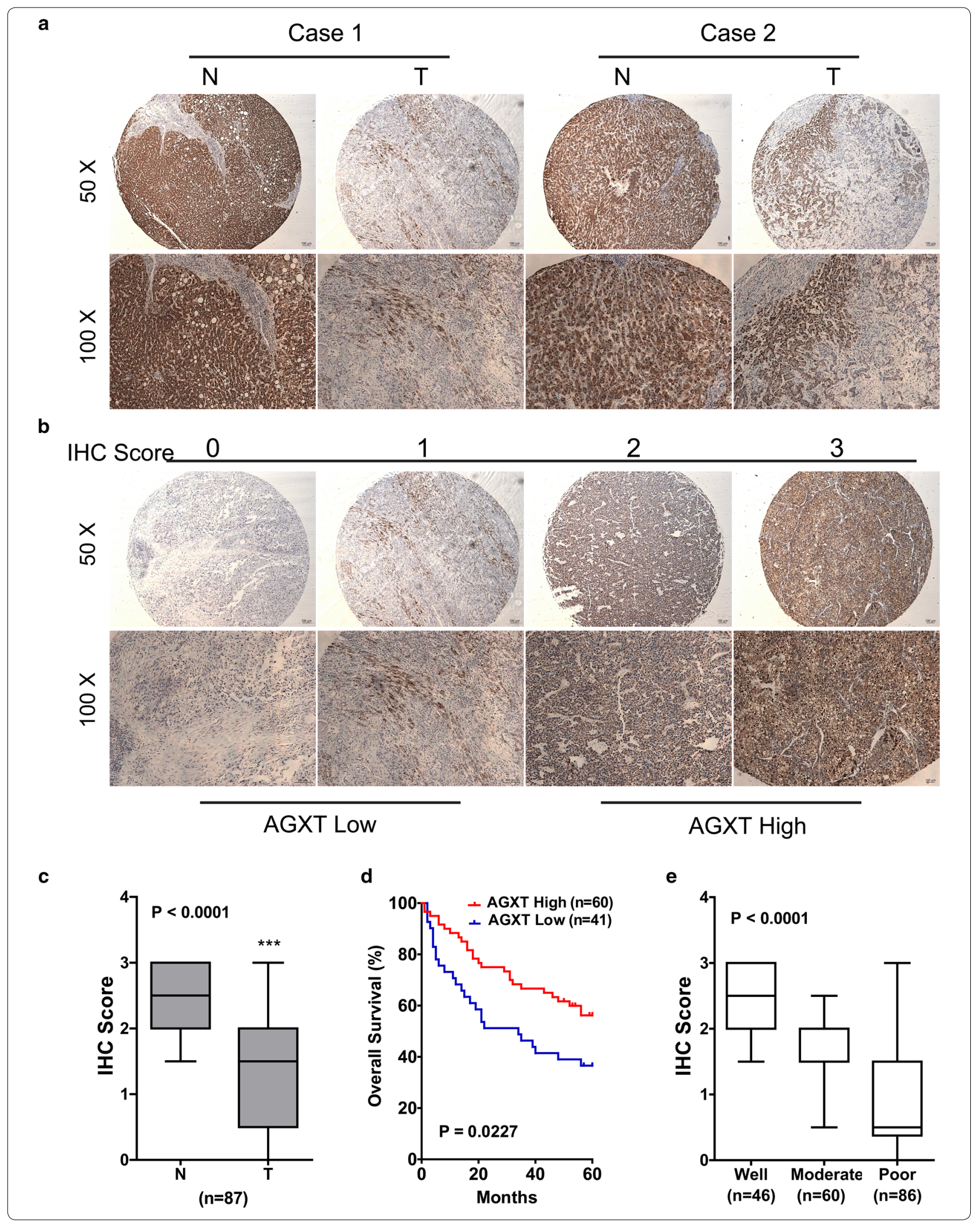




\begin{tabular}{|c|c|c|c|}
\hline \multirow[t]{2}{*}{ Variable } & \multicolumn{2}{|l|}{ AGXT } & \multirow[t]{2}{*}{ P-value } \\
\hline & Low $(n=41)$ & $\begin{array}{l}\text { High } \\
\text { and moderate } \\
(n=60)\end{array}$ & \\
\hline Age & & & 0.277 \\
\hline$\leq 50$ & 16 & 30 & \\
\hline$>50$ & 25 & 30 & \\
\hline Gender & & & 0.257 \\
\hline Male & 28 & 47 & \\
\hline Female & 13 & 13 & \\
\hline $\mathrm{HBsAg}$ & & & 0.092 \\
\hline Positive & 34 & 56 & \\
\hline Negative & 6 & 3 & \\
\hline Portal vein tumor thrombus & & & 0.930 \\
\hline No & 17 & 38 & \\
\hline Yes & 1 & 2 & \\
\hline Cirrhosis & & & 0.499 \\
\hline Yes & 28 & 40 & \\
\hline No & 8 & 16 & \\
\hline Tumor number & & & 0.882 \\
\hline Single & 13 & 31 & \\
\hline Multiple & 3 & 8 & \\
\hline Serum AFP (ng/ml) & & & 0.078 \\
\hline$\leq 300$ & 15 & 32 & \\
\hline$>300$ & 17 & 16 & \\
\hline Vascular invasion & & & 0.984 \\
\hline Yes & 17 & 25 & \\
\hline No & 24 & 35 & \\
\hline Tumour size (cm) & & & 0.955 \\
\hline$\leq 3$ & 19 & 27 & \\
\hline$>3$ & 22 & 32 & \\
\hline Tumor differentiation & & & $<0.0001^{*}$ \\
\hline Well & 0 & 20 & \\
\hline Moderate & 7 & 32 & \\
\hline Poor & 34 & 8 & \\
\hline TNM & & & 0.720 \\
\hline 1 & 18 & 25 & \\
\hline$\|$ & 17 & 24 & \\
\hline III-IV & 3 & 6 & \\
\hline
\end{tabular}

*Significant $\mathrm{P}$ values are highlighted in italic

\section{Loss of AGXT expression promoted the malignant phenotypes of HCC cell lines}

To further understand the role of AGXT in HCC progression, the biofunctions of AGXT was investigated in human HCC cell lines. First, we compared the expression of AGXT in a panel of HCC cell lines by quantitative real-time PCR. It turned out that Huh-7 exhibited very high level of AGXT, whereas others, such as HepG2,
SMMC-7721, MHCC97-H and SK-Hep1 expressed little AGXT (Fig. 6a). Compared to AGXT high-expression Huh-7, AGXT low-expression HepG2 showed higher proliferation ability $(\mathrm{P}<0.0001)$ and greater migration activity $(\mathrm{P}<0.0001)$ (Fig. 6b, c). To further verify the effects of reduced AGXT expression on HCC cells, AGXT high-expression Huh-7 cells were transfected with siAGXT. The transfection efficiency exceeded $95 \%$ as it was evaluated by Cy3-siTC. The expression of AGXT was effectively down-regulated by siAGXT at both mRNA and protein levels as validated by RT-PCR and western blot analyses (Fig. 6d). By CCK8 proliferation assay and transwell migration assay, we verified that reduced AGXT expression in Huh-7 accelerated cell proliferation $(\mathrm{P}<0.0001)$ and promoted cell migration $(\mathrm{P}<0.0001)$ (Fig. 6e, f).

The potential effects of AGXT on cell cycle and apoptosis in HCC cells were further examined by flow cytometry. We found that siAGXT treated HCC cells showed a cell cycle shift from G0/G1 to $\mathrm{S}$ and G2/M phases (Fig. 6g) indicating enhanced proliferating activity, which was consistent with the CCK8 proliferation assays mentioned earlier. In apoptosis assays, early apoptotic cells were Annexin V-FITC (+) PI (-) (low right quadrant) and late apoptotic/necrotic cells were Annexin V-FITC $(+)$ PI $(+)$ (upper right quadrant). The proportions of both early apoptotic and late apoptotic/necrotic cells increased as the expression of AGXT decreased (Fig. 6h). Increased apoptosis/necrosis along with increased proliferation suggested the controls that integrate cell proliferation and death in normal tissues persist during malignancy. Proapoptotic factors can induce proliferation of neighboring surviving cells to replace dying cells [64, 65]. Increased apoptosis/necrosis along with increased proliferation are always associated with malignant tumors, and are more noticeable in high grade tumors $[64,66]$.

\section{Discussion}

To date, a large proportion of existed systematic reviews or meta studies on HCC markers were about serum markers $[67,68]$, and others were focused on one or a set of genes $[69,70]$, inflammatory-based markers [71, 72]. Due to the differences across experimental methods, sample size and quality, inconsistent annotation and the methods used for data processing and analysis, it is difficult to do integrated bioinformatics analysis with microarray data from different platforms, and sometimes even the raw data are not available in public databases, so there are very few studies that combined the data form different HCC gene expression profiles [73, 74]. Zhang et al. reanalyzed three publicly available datasets of gene expression profiles in the Oncomine database; 

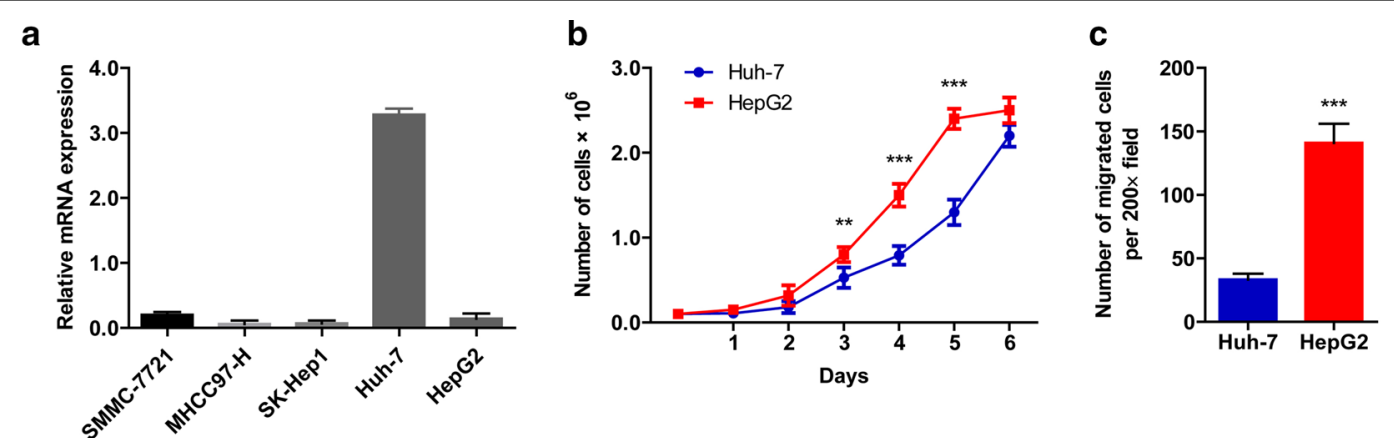

d
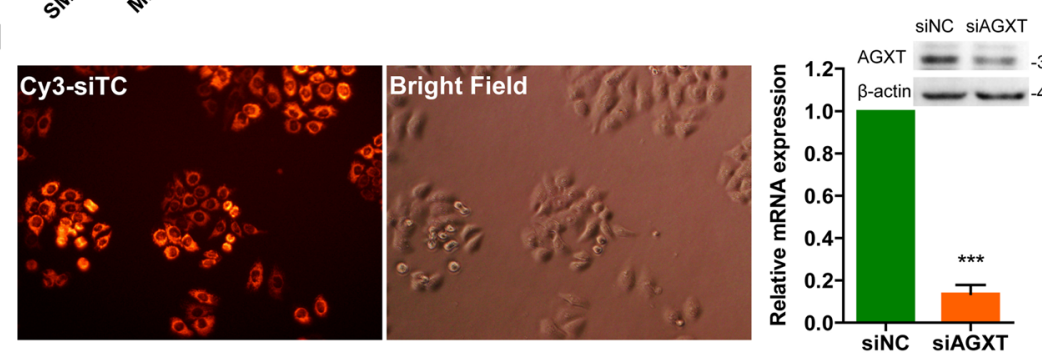

f
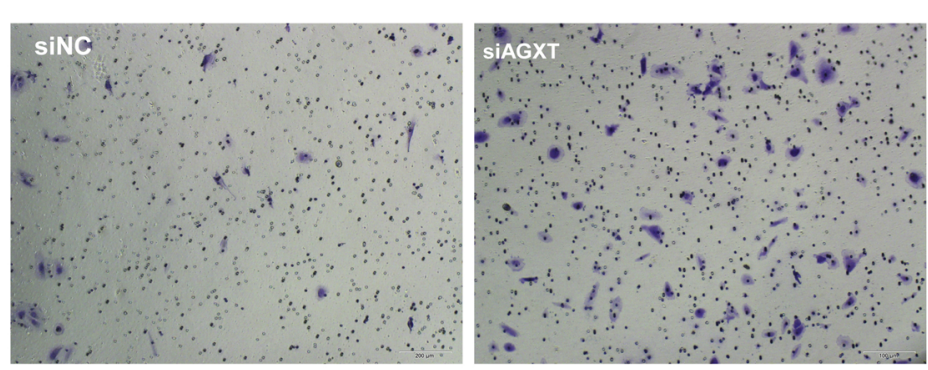

g

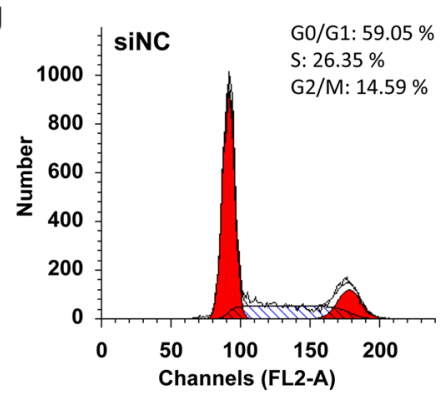

h

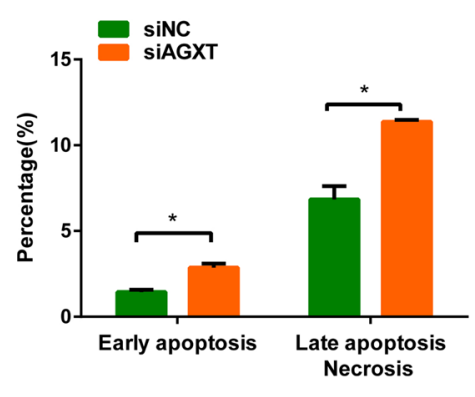

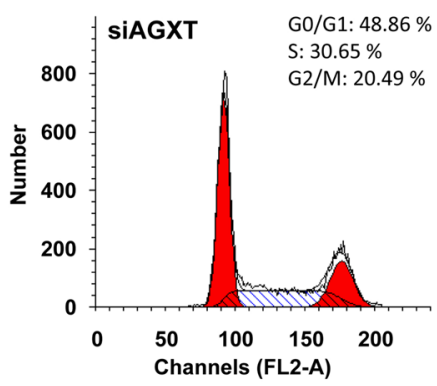
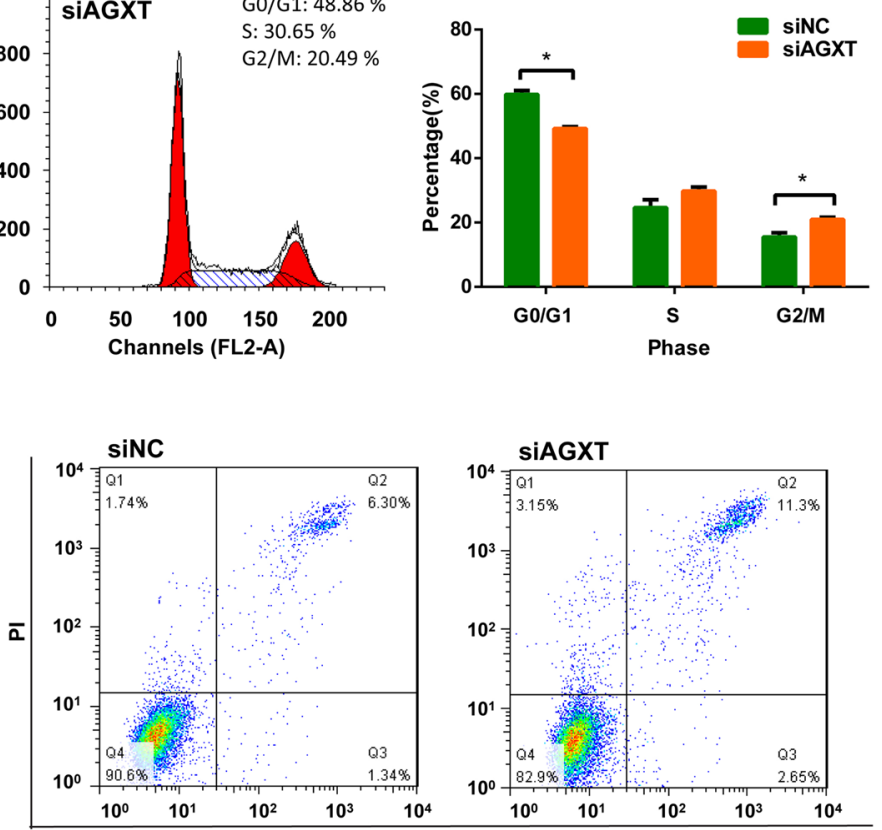
(See figure on previous page.)

Fig. 6 Loss of AGXT expression promoted the malignant phenotypes of HCC cell in vitro. a The mRNA expressions of AGXT in a panel of HCC cell lines were detected by quantitative real-time PCR. b Proliferation ability of HCC cells was measured by cell counting. $\mathbf{c}$ Transwell migration assay for HCC cells. $\mathbf{d}$ The transfection efficiency of siRNA was measured $48 \mathrm{~h}$ after Cy3-siTC transfection (original magnification, $\times 400$ ); and the knockdown efficiency of siAGXT in Huh7 cells was determined by quantitative real-time PCR and western blot. e Proliferation of siAGXT transfected Huh7 cells was measured by CCK8 assay. $\mathbf{f}$ Transwell migration assay for siAGXT transfected Huh7 cells, representative images and quantitative results were provided (original magnification, $\times 200$ ). $\mathbf{g}$ Cell cycle assay for siAGXT transfected Huh7 cells, representative histogram of the gated cells in G0/ G1, S, and G2/M phases and quantitative analyses, at least 10,000 cells per sample. $\mathbf{h}$ Apoptosis assay, representative histogram and quantitative analyses of the cells in each phase, at least 10,000 cells per sample. Each bar represents mean \pm SD of the data obtained from three independent experiments. ${ }^{* * *} \mathrm{P}<0.0001,{ }^{* * P}<0.001,{ }^{*} \mathrm{P}<0.05$

they identified 17 hub genes (10 unregulated and 7 down-regulated in HCC tissues). Among the 17 genes, 13 genes (SMAD2, PTK2, MAPK1, HDAC1, CDC25A, IGFI, FOS, ESR1, EGFR, SOCS3, SP1, YY1 and JUNB) have been identified as an HCC-related gene [73]. Shi et al. analyzed the integrated microarray data from four independent studies (GSE14520, GSE25097, GSE36376 and GSE57957) from public databases Gene Expression Omnibus (GEO, http://www.ncbi.nlm.nih.gov/geo); they found that KLHL21 was a potential target for therapeutic intervention [74].

In the present study, we conducted a systematic review of studies that reported cDNA microarray data and differentially expressed genes between HCC tumor and nontumor tissues. We searched the PubMed databases for eligible studies published in English-language before July 2016 and retrieved 392 articles. The list of differentially expressed genes from 43 carefully designed studies that satisfied further inclusion criteria were summarized. A total of $1917 \mathrm{HCC}$ patients were involved and 2022 non redundant abnormally expressed genes in HCC were extracted. The frequencies of reported genes were ranked. We finally obtained a list of only five genes (AGXT; ALDOB; CYP2E1; IGFBP3; TOP2A) that were differentially expressed in tumor and nontumor tissues across studies, and were significantly correlated to HCC prognosis. Among the five genes, four (ALDOB; CYP2E1; IGFBP3; TOP2A) were well documented HCC related genes, while AGXT was mostly studies in primary hyperoxaluria type $1[57,58]$, but had not been reported in HCC.

Unlike the unstable changes of the other four genes, the expression of AGXT was constantly reduced in tumors compared to nontumor tissues in a variety of malignant, including liver cancer, gastric cancer, kidney cancer, lung cancer and pancreatic cancer (Additional file 3: Table S3). In the present study, we found that the expression of AGXT reflected the differentiation of HCC and reduced AGXT expression was correlated to poor overall survival of HCC patients. Knocking down of AGXT in HCC cell line could induce a cell cycle shift from G0/G1 to $\mathrm{S}$ and $\mathrm{G} 2 / \mathrm{M}$ together with enhanced cell proliferation, increased cell death and migration, suggesting a role of AGXT in promoting tumor progression. We provided a high level of evidence on AGXT to serve as a new biomarker and prognostic factor that related to tumor differentiation and progression for HCC.

AGXT gene encoded an enzyme called alanine-glyoxylate and serine-pyruvate aminotransferase which is found in liver cells, specifically within peroxisomes. Serinepyruvate aminotransferase converts glyoxylate to glycine and is involved in glyoxylate detoxification. The role of AGXT in tumor biology has not been reported yet. One relevant observation is that the metabolic changes to pyruvate and glyoxylate might contribute to the improved therapeutic effects of sorafenib and everolimus combination therapy for HCC [75]. The underlying mechanisms for the contribution of decreased AGXT expression to $\mathrm{HCC}$ progression deserved further investigation.

As we were preparing the manuscript, another study group reported AGXT as a novel immunohistochemical marker for the diagnosis of HCC, and demonstrated comparable specificity and higher sensitivity of AGXT compared to arginase-1 [76]. The reason why they were interested in AGXT was uninterpreted; they only mentioned that AGXT was expressed in the liver exclusively. Their finding reaffirmed that AGXT as a new HCC biomarker, and backed up the feasibility and necessity of systematic review on discovering new and reliable biomarkers for HCC as well as for other cancer.

\section{Conclusion}

In conclusion, the present study was an effort to merge abnormally expressed genes in hepatocellular carcinoma form multiple independent studies, which increased sample size and enhanced reliability. The data of present study identified a list of only five high frequency prognostic genes and emphasized a critical role of AGXT deletion during $\mathrm{HCC}$ progression, indicated a potential relevance of AGXT restoration for HCC therapy. Further welldesigned and larger sample studies are surely warranted to identify the role of the AGXT in the development and progression of HCC and other malignant tumors. 


\section{Supplementary information}

Supplementary information accompanies this paper at https://doi. org/10.1186/s12967-019-02138-5.

Additional file 1: Table S1. Clinical characteristics of patients in HCC tissue array cohort at the time of surgery $(n=101)$.

Additional file 2: Table S2. Frequency of the abnormally expressed genes in $\mathrm{HCC}$

Additional file 3: Table S3. The publication history and the expression of the 37 high frequency genes in liver cancer and other malignant tumors.

Additional file 4: Figure S1. Expression for AGXT Gene. (A) mRNA expression in normal human tissues from GTEx, Illumina, BioGPS, and CGAP SAGE for AGXT Gene. (B) Integrated Proteomics: protein expression in normal tissues and cells from ProteomicsDB, MaxQB, and MOPED for AGXT Gene. (https://www.genecards.org/).

\section{Abbreviations}

AGXT: alanine-glyoxylate and serine-pyruvate aminotransferase; ALDOB: aldolase B; CYP2E1: cytochrome P450 family 2 subfamily E member 1; HBV: hepatitis B virus; HCC: hepatocellular carcinoma; HCV: hepatitis C virus; IHC: immunohistochemistry; IGFBP3: insulin-like growth factor binding protein-3; OS: overall survival; TMAs: tissue microarrays; TOP2A: topoisomerase $2 a$.

\section{Acknowledgements}

The authors acknowledge K. D. and YL. J. for their assistant in screening of relevant publications.

\section{Authors' contributions}

$J \amalg J$ and YS: conceived and designed the experiments. YFS and SQS performed the experiments and analyzed the experiments data. WCL and XJY: data acquisition and data analysis. BL and XJZ: follow up and quality control of data. $J$ J, YS and YFS wrote the manuscript. PL reviewed the manuscript. All authors read and approved the final manuscript.

\section{Funding}

This study was supported by Grants from the National Natural Science Foundation of China, No. 81761128018, 81572871; Natural Science Foundation of Jiangsu Province, No. BK20151277; Undergraduate Training Programs for Innovation and Entrepreneurship of Jiangsu Province, No. 201610304034Z, No. 201710304028Z. The funders had no role in study design, data collection, and analysis, decision to publish, or preparation of the manuscript.

\section{Availability of data and materials}

All data included in the present study were presented in the main manuscript.

\section{Ethics approval and consent to participate}

This study was approved by the Ethics Committee of the Affiliated Hospital of Nantong University. The study was performed on the basis of the protocol approved by the 1964 Declaration of Helsinki, and written informed consent was obtained from all patients.

\section{Consent for publication}

Informed consent was obtained from all participants for publication.

\section{Competing interests}

The authors declare that they have no competing interests.

\section{Author details}

${ }^{1}$ Department of Pathology, Medical School of Nantong University, Nantong, China. ${ }^{2}$ Basic Medical Research Centre in Medical College of Nantong University, Nantong, China. ${ }^{3}$ Department of Epidemiology and Medical Statistics, Public Health School of Nantong University, Nantong, China. ${ }^{4}$ Medical School of Nantong University, Nantong, China. ${ }^{5}$ Department of Clinical Biobank, Affiliated Hospital of Nantong University, Nantong, China. ${ }^{6}$ Department of Biostatistics, Public Health School of Shandong University, Jinan, China.
Received: 13 February 2019 Accepted: 13 November 2019

Published online: 26 November 2019

\section{References}

1. Bray F, Ferlay J, Soerjomataram I, Siegel RL, Torre LA, Jemal A. Global cancer statistics 2018: GLOBOCAN estimates of incidence and mortality worldwide for 36 cancers in 185 countries. CA Cancer J Clin. 2018;68:394-424.

2. Torzilli G, Belghiti J, Kokudo N, Takayama T, Capussotti L, Nuzzo G, Vauthey JN, Choti MA, De Santibanes E, Donadon M, et al. A snapshot of the effective indications and results of surgery for hepatocellular carcinoma in tertiary referral centers: is it adherent to the EASL/AASLD recommendations?: an observational study of the HCC East-West study group. Ann Surg. 2013;257:929-37.

3. Zucman-Rossi J, Villanueva A, Nault JC, Llovet JM. Genetic landscape and biomarkers of hepatocellular carcinoma. Gastroenterology. 2015;149(1226-1239):e1224.

4. Ji J, Eggert T, Budhu A, Forgues M, Takai A, Dang H, Ye Q, Lee JS, Kim JH, Greten TF, Wang XW. Hepatic stellate cell and monocyte interaction contributes to poor prognosis in hepatocellular carcinoma. Hepatology. 2015;62:481-95.

5. Kittaka N, Takemasa I, Takeda Y, Marubashi S, Nagano H, Umeshita K, Dono K, Matsubara K, Matsuura N, Monden M. Molecular mapping of human hepatocellular carcinoma provides deeper biological insight from genomic data. Eur J Cancer. 2008;44:885-97.

6. Nam SW, Park JY, Ramasamy A, Shevade S, Islam A, Long PM, Park CK, Park SE, Kim SY, Lee SH, et al. Molecular changes from dysplastic nodule to hepatocellular carcinoma through gene expression profiling. Hepatology. 2005:42:809-18.

7. Lee JD, Yun M, Lee JM, Choi Y, Choi YH, Kim JS, Kim SJ, Kim KS, Yang WI, Park YN, et al. Analysis of gene expression profiles of hepatocellular carcinomas with regard to $18 \mathrm{~F}$-fluorodeoxyglucose uptake pattern on positron emission tomography. Eur J Nucl Med Mol Imaging. 2004;31:1621-30

8. Smith MW, Yue ZN, Geiss GK, Sadovnikova NY, Carter VS, Boix L, Lazaro CA Rosenberg GB, Bumgarner RE, Fausto NJCR. Identification of novel tumor markers in hepatitis $C$ virus-associated hepatocellular carcinoma. Cancer Res. 2003;63:859-64.

9. Gao W, Kondo Y, Shen L, Shimizu Y, Sano T, Yamao K, Natsume A, Goto Y, Ito $M$, Murakami $\mathrm{H}$, et al. Variable DNA methylation patterns associated with progression of disease in hepatocellular carcinomas. Carcinogenesis. 2008:29:1901-10.

10. Hamaguchi T, lizuka N, Tsunedomi R, Hamamoto Y, Miyamoto T, lida M, Tokuhisa Y, Sakamoto K, Takashima M, Tamesa T. Glycolysis module activated by hypoxia-inducible factor 1alpha is related to the aggressive phenotype of hepatocellular carcinoma. Int J Oncol. 2008;33:725-31.

11. Nagai K, Kohno K, Chiba M, Pak S, Murata S, Fukunaga K, Kobayashi A, Yasue $\mathrm{H}$, Ohkohchi N. Differential expression profiles of sense and antisense transcripts between HCV-associated hepatocellular carcinoma and corresponding non-cancerous liver tissue. Int J Oncol. 2012;40:1813-20.

12. Derambure C. Genome-wide differences in hepatitis C-vs alcoholism-associated hepatocellular carcinoma. World J Gastroenterol. 2008;14:1749-58.

13. Sakai $Y$, Honda M, Fujinaga H, Tatsumi I, Mizukoshi E, Nakamoto Y, Kaneko S. Common transcriptional signature of tumor-infiltrating mononuclear inflammatory cells and peripheral blood mononuclear cells in hepatocellular carcinoma patients. Cancer Res. 2008;68:10267-79.

14. Engelmann JC, Amann T, Ott-Rotzer B, Nutzel M, Reinders Y, Reinders J, Thasler WE, Kristl T, Teufel A, Huber CG, et al. Causal modeling of cancerstromal communication identifies PAPPA as a novel stroma-secreted factor activating NFkappaB signaling in hepatocellular carcinoma. PLoS Comput Biol. 2015;11:e1004293.

15. Itzel T, Scholz P, Maass T, Krupp M, Marquardt JU, Strand S, Becker D, Staib $\mathrm{F}$, Binder $\mathrm{H}$, Roessler $\mathrm{S}$, et al. Translating bioinformatics in oncology: guiltby-profiling analysis and identification of KIF18B and CDCA3 as novel driver genes in carcinogenesis. Bioinformatics. 2015;31:216-24. 
16. Yu D, Zhang G, Huang X, Wu C, Tan W, Qiao Y, Chang J, Zhao H, Bi X, Cai J, et al. Relatively small contribution of methylation and genomic copy number aberration to the aberrant expression of inflammationrelated genes in HBV-Related hepatocellular carcinoma. PLOS ONE. 2015;10:e0126836.

17. Shi M, Chen MS, Sekar K, Tan CK, Ooi LL, Hui KM. A blood-based threegene signature for the non-invasive detection of early human hepatocellular carcinoma. Eur J Cancer. 2014;50:928-36.

18. Mayinuer A, Yasen M, Mogushi K, Obulhasim G, Xieraili M, Aihara A, Tanaka S, Mizushima H, Tanaka H, Arii S. Upregulation of protein tyrosine phosphatase type IVA member 3 (PTP4A3/PRL-3) is associated with tumor differentiation and a poor prognosis in human hepatocellular carcinoma. Ann Surg Oncol. 2013;20:305-17.

19. Gehrau RC, Archer KJ, Mas VR, Maluf DG. Molecular profiles of HCV cirrhotic tissues derived in a panel of markers with clinical utility for hepatocellular carcinoma surveillance. PLoS ONE. 2012;7:e40275.

20. Roessler S, Long EL, Budhu A, Chen Y, Zhao X, Ji J, Walker R, Jia HL, Ye QH, Qin $L X$, et al. Integrative genomic identification of genes on $8 p$ associated with hepatocellular carcinoma progression and patient survival. Gastroenterology. 2012;142(957-966):e912.

21. Sato S, Genda T, Hirano K, Tsuzura H, Narita Y, Kanemitsu Y, Kikuchi T, lijima K, Wada R, Ichida T. Up-regulated aldo-keto reductase family 1 member B10 in chronic hepatitis C: association with serum alpha-fetoprotein and hepatocellular carcinoma. Liver Int. 2012;32:1382-90.

22. Yu MC, Lee YS, Lin SE, Wu HY, Chen TC, Lee WC, Chen MF, Tsai CN. Recurrence and poor prognosis following resection of small hepatitis B-related hepatocellular carcinoma lesions are associated with aberrant tumor expression profiles of glypican 3 and osteopontin. Ann Surg Oncol. 2012;19(Suppl 3):S455-63.

23. Zekri A-RN, Hassan ZK, Bahnassy AA, Sherif GM, Eldahshan D, Abouelhoda M, Ali A, Hafez MM. Molecular prognostic profile of Egyptian HCC cases infected with hepatitis C virus. Asian Pac J Cancer Prev. 2012;13:5433-8.

24. Satow R, Shitashige M, Kanai Y, Takeshita F, Ojima H, Jigami T, Honda K, Kosuge T, Ochiya T, Hirohashi S, Yamada T. Combined functional genome survey of therapeutic targets for hepatocellular carcinoma. Clin Cancer Res. 2010;16:2518-28.

25. De Giorgi V, Monaco A, Worchech A, Tornesello M, Izzo F, Buonaguro L, Marincola FM, Wang E, Buonaguro FM. Gene profiling, biomarkers and pathways characterizing HCV-related hepatocellular carcinoma. J Transl Med. 2009;7:85

26. Sugawara M, Okamoto K, Kadowaki T, Kusano K, Fukamizu A, Yoshimura T. Expressions of cytochrome P450, UDP-glucuronosyltranferase, and transporter genes in monolayer carcinoma cells change in subcutaneous tumors grown as xenografts in immunodeficient nude mice. Drug Metab Dispos. 2010;38:526-33.

27. Guo K, Liu Y, Zhou H, Dai Z, Zhang J, Sun R, Chen J, Sun Q, Lu W, Kang X, Chen P. Involvement of protein kinase $C$ beta-extracellular signal-regulating kinase 1/2/p38 mitogen-activated protein kinase-heat shock protein 27 activation in hepatocellular carcinoma cell motility and invasion. Cancer Sci. 2008;99:486-96.

28. Skawran B, Steinemann D, Weigmann A, Flemming P, Becker T, Flik J, Kreipe H, Schlegelberger B, Wilkens L. Gene expression profiling in hepatocellular carcinoma: upregulation of genes in amplified chromosome regions. Mod Pathol. 2008;21:505-16.

29. Yamashita T, Forgues M, Wang W, Kim JW, Ye Q, Jia H, Budhu A, Zanetti KA, Chen Y, Qin LX, et al. EpCAM and alpha-fetoprotein expression defines novel prognostic subtypes of hepatocellular carcinoma. Cancer Res. 2008;68:1451-61.

30. Lin CS, Kuo CL, Wang JP, Cheng JS, Huang ZW, Chen CF. Growth inhibitory and apoptosis inducing effect of Perilla frutescens extract on human hepatoma HepG2 cells. J Ethnopharmacol. 2007;1 12:557-67.

31. Liu Y, Zhu X, Zhu J, Liao S, Tang Q, Liu K, Guan X, Zhang J, Feng ZJ. Identification of differential expression of genes in hepatocellular carcinoma by suppression subtractive hybridization combined cDNA microarray. Oncol Rep. 2007;18:943-51.

32. Wang $S M$, Ooi LL, Hui KM. Identification and validation of a novel gene signature associated with the recurrence of human hepatocellular carcinoma. Clin Cancer Res. 2007;13:6275-83.

33. Wang F, Anderson PW, Salem N, Kuang Y, Tennant BC, Lee ZJ. Gene expression studies of hepatitis virus-induced woodchuck hepatocellular carcinoma in correlation with human results. Int J Oncol. 2007:30:33-44.
34. Dannenberg LO, Edenberg HJ. Epigenetics of gene expression in human hepatoma cells: expression profiling the response to inhibition of DNA methylation and histone deacetylation. BMC Genomics. 2006;7:181.

35. Chen ZE, Crone KG, Watson MA, Pfeifer JD, Wang HL. Identification of a unique gene expression signature that differentiates hepatocellular adenoma from well-differentiated hepatocellular carcinoma. Am J Surg Pathol. 2005;29:1600-8.

36. Ge X, Yamamoto S, Tsutsumi S, Midorikawa Y, Ihara S, Wang SM, Aburatani $\mathrm{H}$. Interpreting expression profiles of cancers by genome-wide survey of breadth of expression in normal tissues. Genomics. 2005;86:127-41.

37. lizuka N, Oka M, Yamada-Okabe H, Mori N, Tamesa T, Okada T, Takemoto N, Sakamoto K, Hamada K, Ishitsuka H, et al. Self-organizing-map-based molecular signature representing the development of hepatocellular carcinoma. FEBS Lett. 2005;579:1089-100.

38. Matoba K, lizuka N, Gondo T, Ishihara T, Yamada-Okabe H, Tamesa T, Takemoto N, Hashimoto K, Sakamoto K, Miyamoto T, et al. Tumor HLA-DR expression linked to early intrahepatic recurrence of hepatocellular carcinoma. Int J Cancer. 2005;115:231-40.

39. Wong N, Chan KY, Macgregor PF, Lai PB, Squire JA, Beheshti B, Albert M, Leung TW. Transcriptional profiling identifies gene expression changes associated with IFN-alpha tolerance in hepatitis C-related hepatocellular carcinoma cells. Clin Cancer Res. 2005;11:1319-26.

40. Kai B, Vreden S, Haddad R, Beckebaum S, Stippel D, Flemming P, Nussbaum T, Caselmann WH, Haab BB, Schirmacher PJCR. Molecular profiling of human hepatocellular carcinoma defines mutually exclusive interferon regulation and insulin-like growth factor II overexpression. Cancer Res. 2004;64:6058-64.

41. Chen X, Higgins J, Cheung ST, Li R, Mason V, Montgomery K, Fan ST, van de Rijn M, So S. Novel endothelial cell markers in hepatocellular carcinoma. Mod Pathol. 2004;17:1198-210.

42. Kurokawa Y, Matoba R, Nagano H, Sakon M, Takemasa I, Nakamori S, Dono K, Umeshita K, Ueno N, Ishii S. Molecular prediction of response to 5-fluorouracil and interferon-alpha combination chemotherapy in advanced hepatocellular carcinoma. Clin Cancer Res. 2004;10:6029-38.

43. Kim JW, Ye Q, Forgues M, Chen Y, Budhu A, Sime J, Hofseth LJ, Kaul R, Wang XW. Cancer-associated molecular signature in the tissue samples of patients with cirrhosis. Hepatology. 2004;39:518-27.

44. Chung EJ, Sung YK, Farooq M, Kim Y, Im S, Tak WY, Hwang YJ, Kim YI, Han HS, Kim MK. Cells: gene expression profile analysis in human hepatocellular carcinoma by cDNA microarray. Mol Cells. 2002;14:382-7.

45. lizuka N, Oka M, Yamada-Okabe H, Mori N, Tamesa T, Okada T, Takemoto $\mathrm{N}$, Tangoku A, Hamada K, Nakayama H, et al. Comparison of gene expression profiles between hepatitis B virus- and hepatitis C virus-infected hepatocellular carcinoma by oligonucleotide microarray data on the basis of a supervised learning method. Cancer Res. 2002;62:3939-44.

46. Lee JS, Thorgeirsson SS. Functional and genomic implications of global gene expression profiles in cell lines from human hepatocellular cancer. Hepatology. 2002;35:1134-43.

47. Okabe H, Satoh S, Kato T, Kitahara O, Yanagawa R, Yamaoka Y, Tsunoda T, Furukawa Y, Nakamura Y. Genome-wide analysis of gene expression in human hepatocellular carcinomas using cDNA microarray: identification of genes involved in viral carcinogenesis and tumor progression. Cancer Res. 2001;61:2129-37.

48. Tao QF, Yuan SX, Yang F, Yang S, Yang Y, Yuan JH, Wang ZG, Xu QG, Lin KY, Cai J, et al. Aldolase B inhibits metastasis through Ten-Eleven Translocation 1 and serves as a prognostic biomarker in hepatocellular carcinoma. Mol Cancer. 2015;14:170.

49. Wu J, Dan C, Zhao HB, Xiao CX, Liu YP, Si LJ, Ren JL, Guleng B. ALDOB acts as a novel $\mathrm{HBsAg}$-binding protein and its coexistence inhibits cisplatin-induced HepG2 cell apoptosis. Crit Rev Eukaryot Gene Expr. 2014:24:181-91.

50. Peng SY, Lai PL, Pan HW, Hsiao LP, Hsu HC. Aberrant expression of the glycolytic enzymes aldolase B and type II hexokinase in hepatocellular carcinoma are predictive markers for advanced stage, early recurrence and poor prognosis. Oncol Rep. 2008;19:1045-53.

51. Wang J, Li YC, Deng M, Jiang HY, Guo LH, Zhou WJ, Ruan B. Serum insulinlike growth factor- 1 and its binding protein 3 as prognostic factors for the incidence, progression, and outcome of hepatocellular carcinoma: a systematic review and meta-analysis. Oncotarget. 2017;8:81098-108. 
52. Han JJ, Xue DW, Han QR, Liang XH, Xie L, Li S, Wu HY, Song B. Induction of apoptosis by IGFBP3 overexpression in hepatocellular carcinoma cells. Asian Pac J Cancer Prev. 2014;15:10085-9.

53. Huynh H, Chow PK, Ooi LL, Soo KC. A possible role for insulin-like growth factor-binding protein-3 autocrine/paracrine loops in controlling hepatocellular carcinoma cell proliferation. Cell Growth Differ. 2002;13:115-22.

54. Liu W, Tian F, Dai L, Chai Y. Cytochrome P450 2E1 gene polymorphism and alcohol drinking on the risk of hepatocellular carcinoma: a meta-analysis. Mol Biol Rep. 2014:41:7645-50.

55. Yu MW, Gladek-Yarborough A, Chiamprasert S, Santella RM, Liaw YF, Chen CJ. Cytochrome P450 2E1 and glutathione S-transferase M1 polymorphisms and susceptibility to hepatocellular carcinoma. Gastroenterology. 1995; 109:1266-73.

56. Tsutsumi M, Matsuda Y, Takada A. Role of ethanol-inducible cytochrome $\mathrm{P}-4502 \mathrm{E} 1$ in the development of hepatocellular carcinoma by the chemical carcinogen, N-nitrosodimethylamine. Hepatology. 1993;18:1483-9.

57. Panvichian R, Tantiwetrueangdet A, Angkathunyakul N, Leelaudomlipi S. TOP2A amplification and overexpression in hepatocellular carcinoma tissues. Biomed Res Int. 2015;2015:381602.

58. Zhou L, Du Y, Kong L, Zhang X, Chen Q. Identification of molecular target genes and key pathways in hepatocellular carcinoma by bioinformatics analysis. Onco Targets Ther. 2018;11:1861-9.

59. Salido EC, Li XM, Lu Y, Wang X, Santana A, Roy-Chowdhury N, Torres A, Shapiro $\sqcup$, Roy-Chowdhury J. Alanine-glyoxylate aminotransferasedeficient mice, a model for primary hyperoxaluria that responds to adenoviral gene transfer. Proc Natl Acad Sci USA. 2006;103:18249-54.

60. Fodor K, Wolf J, Erdmann R, Schliebs W, Wilmanns M. Molecular requirements for peroxisomal targeting of alanine-glyoxylate aminotransferase as an essential determinant in primary hyperoxaluria type 1. PLoS Biol. 2012;10:e1001309.

61. Roessler S, Jia HL, Budhu A, Forgues M, Ye QH, Lee JS, Thorgeirsson SS, Sun Z, Tang ZY, Qin LX, Wang XW. A unique metastasis gene signature enables prediction of tumor relapse in early-stage hepatocellular carcinoma patients. Cancer Res. 2010;70:10202-12.

62. Chen X, Cheung ST, So S, Fan ST, Barry C, Higgins J, Lai KM, Ji J, Dudoit S, $\mathrm{Ng} \mathrm{IO}$, et al. Gene expression patterns in human liver cancers. Mol Biol Cell. 2002;13:1929-39.

63. Wurmbach E, Chen YB, Khitrov G, Zhang W, Roayaie S, Schwartz M, Fiel I, Thung S, Mazzaferro V, Bruix J, et al. Genome-wide molecular profiles of HCV-induced dysplasia and hepatocellular carcinoma. Hepatology. 2007;45:938-47.

64. Wang RA, Li QL, Li ZS, Zheng PJ, Zhang HZ, Huang XF, Chi SM, Yang AG, Cui R. Apoptosis drives cancer cells proliferate and metastasize. J Cell Mol Med. 2013;17:205-11.
65. Ryoo HD, Bergmann A. The role of apoptosis-induced proliferation for regeneration and cancer. Cold Spring Harb Perspect Biol. 2012;4:a008797.

66. Parton M, Dowsett M, Smith I. Studies of apoptosis in breast cancer. BMJ. 2001;322:1528-32.

67. Hu B, Tian X, Sun J, Meng X. Evaluation of individual and combined applications of serum biomarkers for diagnosis of hepatocellular carcinoma: a meta-analysis. Int J Mol Sci. 2013;14:23559-80.

68. Okajima W, Komatsu S, Ichikawa D, Miyamae M, Kawaguchi T, Hirajima S, Ohashi T, Imamura T, Kiuchi J, Arita T, et al. Circulating microRNA profiles in plasma: identification of miR-224 as a novel diagnostic biomarker in hepatocellular carcinoma independent of hepatic function. Oncotarget. 2016;7:53820-36

69. Lee DW, Jang MJ, Lee KH, Cho EJ, Lee JH, Yu SJ, Kim YJ, Yoon JH, Kim TY, Han SW, et al. TTP as a surrogate endpoint in advanced hepatocellular carcinoma treated with molecular targeted therapy: meta-analysis of randomised controlled trials. Br J Cancer. 2016;115:1201-5.

70. Liang C, Li W, Ge H, Zhang K, Li G, Wu J. Role of Beclin1 expression in patients with hepatocellular carcinoma: a meta-analysis. Onco Targets Ther. 2018;11:2387-97.

71. Zhang $A B$, Qian YG, Zheng SS. Prognostic significance of regulatory $T$ lymphocytes in patients with hepatocellular carcinoma. J Zhejiang Univ Sci B. 2016;17:984-91.

72. Qi X, Li J, Deng H, Li H, Su C, Guo X. Neutrophil-to-lymphocyte ratio for the prognostic assessment of hepatocellular carcinoma: a systematic review and meta-analysis of observational studies. Oncotarget. 2016;7:45283-301.

73. Zhang Y, Wang S, Li D, Zhnag J, Gu D, Zhu Y, He F. A systems biologybased classifier for hepatocellular carcinoma diagnosis. PLoS ONE. 2011;6:e22426

74. Shi L, Zhang W, Zou F, Mei L, Wu G, Teng Y. KLHL21, a novel gene that contributes to the progression of hepatocellular carcinoma. BMC Cancer. 2016;16:815.

75. Zheng JF, Lu J, Wang XZ, Guo WH, Zhang JX. Comparative metabolomic profiling of hepatocellular carcinoma cells treated with sorafenib monotherapy vs. sorafenib-everolimus combination therapy. Med Sci Monit. 2015;21:1781-91.

76. Zhao CL, Hui Y, Wang LJ, Yang D, Yakirevich E, Mangray S, Huang CK, Lu S. Alanine-glyoxylate aminotransferase 1 (AGXT1) is a novel marker for hepatocellular carcinomas. Hum Pathol. 2018;80:76-81.

\section{Publisher's Note}

Springer Nature remains neutral with regard to jurisdictional claims in published maps and institutional affiliations. 